\title{
The Influence of Social Support on Entrepreneurial Inclination among Business Students in Indonesia
}

\author{
Muhammad Amsal Sahban 1*, Subramaniam Sri Ramalu², Ruswiati Syahputra² \\ ${ }^{1}$ STIM Lasharan Jaya Makassar, Indonesia \\ 2University of Utara Malaysia, Sintok, Kedah, Malaysia \\ *amsalsahban@gmail.com
}

\begin{abstract}
The objective of this study is to investigate the influence of social support on student's inclination toward entrepreneurship. It also aims to test whether gender can moderate the relationship between SS and entrepreneurial intention among business students in Indonesia. Quantitative analysis was conducted using SPSS version 22 . This study conveniently distributed 1,230 self-administrated questionnaires to the business students at public and private universities in Indonesia. This data collection process yielded back with 381 usable responses that were used in the statistical analysis for assessing the relationship between SS and EI as well asthe difference between male and female students in terms of entrepreneurial intention.This study reveals that, there is a positive relationship between social support system and student's inclination toward entrepreneurship and there is a difference between male and female students in terms of entrepreneurial intention.
\end{abstract}

Keywords: Social Support, Entrepreneurial Intention, Business Students, Quantitative Study

\section{Introduction}

Entrepreneurship is a worldwide phenomenon closely associated with economic growth. Entrepreneurs are the "engines" that can accelerate economic growth (Acs, 2006; Baron \& Shane, 2008). They have brought about enormous positive contributions to a country's economic growth and social development. As mentioned by Morrison, Breen and Ali (2003), entrepreneurs play a pivotal role in creating jobs, innovating, creating wealth, improving health and even in economic advancement. Since entrepreneurship is synonymous with self-employment, it is believed to be an effective strategy for handling the issue of employability, particularly among the youth (Koe, Sa'ari, Majid \& Ismail, 2012). Entrepreneurship entities enable reduction in the unemployment rate or what has been termed as the Schumpeter Effect (Musa \& Semasinghe, 2013; Schumpeter, 1934). Apart from that, the unemployment rate among youngsters continues to grow nowadays since the number of youth in Indonesia aged below 30 years dominates more than half of the total population. Consequently, Indonesia has a huge number of workforces. This can trigger a demographic disaster if these workers cannot be absorbed by industries (Indonesia-investments, 2015). The World Bank representative recently gave a warning on Indonesia's unemployment problem among youth. It is due to the fact that the highest rate of unemployment in Indonesia is dominated by people aged 15 to 24 years. This is very ironic since the fresh university graduates, vocational school graduates as well as secondary school graduates face difficulty in looking for a job (Indonesia-investments, 2014).

Based on the report, there are around $20 \%$ of Indonesia's young men and one-third of the young women beingneither unemployed nor going to school. The total number of young men aged 15 to 24 years in Indonesia reached approximately 20.5 million; and the total number of young women aged 15 to 24 years is around 20.2 million. Although the number of unemployed females has reduced significantly compared to their male counterparts, gender disparity is still a challenge in Indonesia. Despite several key areas like education and health showing considerable progress, there are still many women working in the informal sector (twice as many as the number of men). Moreover, they are paid lower wages compared to men for similar work (Indonesia-investments, 2014). However, economic development cannot be realized without active participation of women in all segments of life (Sarfaraz, Faghih \& Majd, 2014). Many scholars have agreed that women can play a pivotal role in entrepreneurship activities. Women's contribution to economic development mainly depends on equal support as for men from relevant institutions. Despite women comprising about $50 \%$ of the world's population, they have less opportunity to take part in decision-making (Revenga \& Shetty, 2012). Since 2008, i.e. after the financial crisis, women have been experiencing greater 
difficulties in earning capital than men and the economic crisis has had an adverse impact on women (Malach-Pines, Lerner, \& Schwartz, 2010). Further, Malach-Pines et al. (2010) found that the number of women entrepreneurs is less than men. The proportion of female entrepreneurs is higher in countries where the general income per capita is at a lower level, where women have to work for a living. However, Balea (2015) argued that women are starting to change the scenario nowadays in terms of an entrepreneurship career even though there are still only a few studies that have focused on the factors influencing entrepreneurial intention among female students (Aaijaz \& Ibrahim, 2013). Thus, there is a need to do further investigation to figure out if there is any difference in terms of gender and entrepreneurial intention, especially among young business students in Indonesia.

Linking education and entrepreneurship with academic institutions clearly points out that universities have become strategic places to nurture entrepreneurial spirit among students (Nastiti, Indarti, \& Rostiani, 2010). Universities have a crucial role in enhancing entrepreneurial education in order to encourage the students to become self-employed once they graduate from university. Therefore, the purpose of higher education institutions is not only to produce graduates to become job seekers, but also job creators. The small number of entrepreneurs in Indonesia indicates the lack of entrepreneurship among the academic community, including their activities in the university environment. The discourse and application of the entrepreneurial university are becoming hot topics in the academic world. However, many of the universities focus on academia and few have plunged into the world of practitioners and entrepreneurship. Among 2,679 private universities and 82 state universities in Indonesia, only a few universities are concerned with the importance of entrepreneurship on campus (Kuswara, 2012). Of the 4.8 million university students in Indonesia, only $17.4 \%$ have the right entrepreneurial spirit and orientation to venture into entrepreneurship after completing their studies. Meanwhile, more than $83 \%$ of university graduates in 2012 preferred to become employees in any of the leading companies or government institutions (Amrullah, 2012; Subachtiar, 2013; Sutarto, 2012; Temonsoejadi.com, 2013). Interestingly, the industries are only able to accommodate up to $10-15 \%$ of the university graduates each year. As a result, the rate of the educated unemployed increases every year (Yusuf, 2012).

According to Indarti (2004), entrepreneurial intention of students in Indonesia is weak. This is reinforced by Hidayat (as cited in Masykur, 2007) who claimed that most students do not have a plan for being selfemployed and are more likely to work in large companies. Intention plays a distinctive role in directing action or behavior. Entrepreneurial intention plays a pivotal role as the link between consideration to engage in entrepreneurship and the entrepreneurial activities conducted by the entrepreneurs themselves (Supatra, 2009). Apart from that, the social support system is considered as a vital aspect for developing entrepreneurial intention. Some related aspects, like environmental support and parental support, play an important role in influencing a person's desire for entrepreneurship (Indarti \& Rostiani, 2008; Lee, Wong, Foo, \& Leung, 2011; Suharti \& Sirine, 2011). This opinion is reinforced by Kasmir (2006), who stated that the support of family, especially parental support, is imperative to increase the motivation to become an entrepreneur. Thus, family support is a primary driving force to foster students' mind-set and motivation (Kasmir, 2006). The jobs of parents are also instrumental for career choice of their children after being graduated from college. According to Mustikawati \& Bachtiar (2008), parents play an undeniably significant role in providing support and motivation to their children to enable them to be socially competent, confident and responsible to realize their intentions to become entrepreneurs. However, studies have found that the presence of significant social risk experienced by an individual in setting up a business is an anxiety of being degraded and derided when the risk of failure is imminent and this will lead to negative opinions of their inability (Phikala \& Vesatlenein, as cited in Astuti, 2009). They lack parental support because parents prefer for their children to be employed rather than being self-employed. Mustikawati \& Bachtiar (2008) found that a number of parents go against their children's wishes to become entrepreneurs and unconsciously try to impose their will on their children's desire.

Students do not have support from their family and friends to do entrepreneurial activities. Instead, their parents and friends always discourage them when they want to start a business (Astuti, 2009; Mustikawati \& Bachtiar, 2008; Susanti, 2012). Most of the parents of university graduates associate the prospects of being an entrepreneur with high risks (Hartanto, 2011). Such pessimistic supposition could sometimes be a hindrance and discourage the children from initiating an entrepreneurship project. Amalia (2012) found 
through her study that students tend to display low self-confidence in their ability to become entrepreneurs. They lack parental support because parents have a preference for their children to be employed rather than be self-employed. Mustikawati \& Bachtiar (2008) found that a number of parents go against their children's passionto become entrepreneurs and unconsciously try to impose their will on their children's desire because being an entrepreneur is perceived as a less prestigious profession in Indonesia, although entrepreneurship activities can significantly contribute to GDP.

Economic development cannot be realized without active participation of women in all segments of life (Sarfaraz, Faghih \& Majd, 2014). Many scholars have agreed that women can play a pivotal role in entrepreneurship activities. Women's contribution to economic development mainly depends on equal support as for men from relevant institutions. Despite women comprising about $50 \%$ of the world's population, they have less opportunity to take part in decision-making (Revenga \& Shetty, 2012). Since 2008, i.e. after the financial crisis, women have been experiencing greater difficulties in earning capital than men and the economic crisis has had an adverse impact on women (Malach-Pines, Lerner, \& Schwartz, 2010). Further, Malach-Pines et al. (2010) found that the number of women entrepreneurs is less than men. The proportion of female entrepreneurs is higher in countries where the general income per capita is at a lower level, where women have to work for a living. However, Balea(2015) argued that women are starting to change the scenario nowadays in terms of an entrepreneurship career even though there are still only a few studies that have focused on the factors influencing entrepreneurial intention among female students (Aaijaz \& Ibrahim, 2013). Thus, there is a need to do further investigation to figure out if there is any difference in terms of gender and entrepreneurial intention, especially among young business students in Indonesia.

\section{Literature Review}

Social Support: Much of the literature on entrepreneurship refers to social support as a potential entrepreneur's beliefs and expectations about the assistance and advice that he/she may receive from his/her social groups(Rani, 2012; Sahban, Kumar, \& Sri Ramalu, 2014). These social groups include primary groups, such as parents, siblings,and spouse; and secondary groups, such as reference groups, comprising friends, colleagues and teachers. Social support is supposed to help and assist the potential entrepreneur in setting up a business or running its activities (León, Descals \& Domínguez, 2007). Sarason et al. (1987) defined social support as the intensity of interaction of entrepreneur with his/her friends and family to whom he/she feels attached to. In other words, social support is the extent of assistance and attachment of an individual with the social group he/she interacts with directly or indirectly who make that individual feel loved and/or cared. Social support, therefore is considered as building blocks for social and psychological integration of entrepreneurs in the society. Experts have classified social support into two main dimensions: support by family; and support by peer groups (Ismail et al., 2013; Rani, 2012; Zafar, Yasin, \& Ijaz, 2012). Social support from these sources tends to play various roles and functions and has different outcomes. Both family and friends' support needs to be considered distinctively because different cultures ascribe a different level of reliance on or benefits from both sources (Procidano \& Heller, 1983).

Family Support: When an individual intends to initiate a new venture, he/she seeks support from multiple sources. Sources of support for the entrepreneurship activity of individuals are usually family, partner and peers to whom they can trust to share the entrepreneurship ideas, the potential problems to be encountered along with the way and the means to handle these issues (Mustikawati \& Bachtiar, 2008). Accordingly, as the closest environment, the support of family can synergize the interest in entrepreneurship. The family plays a pivotal role in inspiring children to choose entrepreneurial careers; parents also tend to encourage their children to take a more challenging career that allows self-freedom and independence (Buang \& Yusof, 2006). Families play a crucial part in the new venture creation process. The role of family support, therefore, needs more consideration by research studies focusing on understanding entrepreneurship. The family relationships serve as strongest business ties in the business networks. Thus, the family of an entrepreneur is considered as offering a number of resources, ranging from professional to non-professional resources, which have a strong effect on new venture creation and its activities.As mentioned by Anderson and Jack (2005) family takes a substantial part in new venture creation; this is due to the strong relationship among family members. Steward (2003) offered the most comprehensive assessment of the role of family support in the entrepreneurial circle. This study has observed the benefits of the family network which include extensive 
tacit knowledge, commitment, access to information and ability to take risks in entrepreneurial efforts. According to Granovetter (1973), the literature on entrepreneurship distinguishes between two elements of network ties which are required for a result oriented entrepreneurial circle. Those people who have close personal relationship and interact quite frequently with other are considered as strong ties network. On the other hand, those people who have a big gap emotionally and make interaction infrequently are considered as weak ties network. Strong relationship usually comes from friends or family, while weak links are mostly associated with business colleagues.

Peer Group Support: Mead (2001) explained peer support as an ecosystem of exchange of help based on principles of mutual respect and shared responsibility, and shared an understanding of resulting benefits. In this way, peer support is not just based on psychological models but it is more about expressing concerned understanding towards each other's issues. It is the feeling of affiliation that individuals in the network have with each other and feel connected with others in a supportive manner. The feeling of being connected or affiliated is founded on a mutually respectful relationship which makes the members learn from each other without being limited by the constraints of traditional relationship. It is therefore imperative that peer group is the point of social interaction between potential entrepreneurs and its advisors. Individual entrepreneurs tend to take decisions to create a new venture because of the influence of their peers. Peer groups consist of people who are already in business and they are supposed to provide technical advice and help to create a supportive environment for business start-up by potential entrepreneurs (Bönte, Falck \& Heblich, 2009). The peer pressure in business results in positive influences by other social entities in the business eco-system, such as media and social networks. It therefore becomes easier for potential entrepreneurs to assume risk, experiment innovation and take business initiatives.

Manski (as cited in Falck et al., 2009) categorized effects of social interaction into two major forms. First is endogenous effects, which refer to the influence or prevalence of certain group behaviour on individual behaviour. It is explained as the situation where peer group's entrepreneurial intentions influence an individual's intention to become an entrepreneur. Second, an exogenous effect, also termed as the contextual effect, which is the influence of reference groups on youth's behavioural intentions to become an entrepreneur. The model developed by Manski (as cited in Falck et al., 2009) explains the effects of peer group's contextual characteristics, such has their family and social situation influences on an individual's entrepreneurial intentions. These exogenous or contextual effects tend to arise from students spending time in their peers' homes or business offices and thus becoming exposed to entrepreneurship. This influences them to consider entrepreneurship as a career option compared to those students who are not exposed to such influence.

Entrepreneurial Intention: Entrepreneurial intention refers to the initial step in the process for establishinga business that is generally long-term (Lee \& Wong, 2004). Krueger (1993) said that entrepreneurial intention refers to one's commitment to start a new business and is a central issue that needs to be considered to understand the process of establishing a new business. Entrepreneurial intention has recently started to receive attention because it is believed that a behavioral intention is a reflection of the actual behavior. Therefore, entrepreneurial intention can be interpreted as the procedure for finding information that can be used to achieve the purpose of establishing a business (Katz \& Gartner, 1988). An individual with the propensity start a business will have the willingness compared to one who does not have the desire to commence a new venture. Krueger, Reilly and Casrud (2000) poisted that intention is found to be a strong predictor of entrepreneurship behavior. Desirability can also be used as a fundamental approach to understand anyone who is in entrepreneurship (Choo \& Wong, 2006). The study by Lee and Wong (2004) emphasizes that entrepreneurial desires or intentions are the initial steps in the long-term process of establishing and running a new venture. A person who has an interest in entrepreneurship will be more prepared and aggressive in efforts to set up a business than others who do not have the interest in entrepreneurship (Nastiti et al., 2010). Gurbuz and Aykol (2008) defined entrepreneurial intention as one's desire to engage in entrepreneurial activities, or in other words, to be self-employed.

Accordingly, based on the definitions of entrepreneurial intention above, it can be inferred that having an interest in entrepreneurship is a critical determinant in the formation of an individual's tendency to initiate and run a business. If a person does not have an interest in entrepreneurship, then everything that will be 
done related to the entrepreneurship process will be more severe than the one who has an interest in entrepreneurship (Segal, Borgia \& Schoenfeld, 2005; Shane, Locke \& Collins, 2003). Essentially, entrepreneurship is the same thing as a job. If an individual likes the job, then of course, he or she will focus on running the processes as well as overcoming any hindrances and obstacles. Indarti and Rostiani(2008) examined the entrepreneurial intentions by looking at three things: (i) personality characteristics; (ii) demographic characteristics; and (iii) environmental characteristics. Personality characteristics include the need for achievement and self-efficacy, whereas demographic characteristics include age, gender, educational background and individual work experience to determine one's entrepreneurial intention. Environmental characteristics include social relationships, physical infrastructure and institutional as well as cultural factors.On the other hand, Mustikawati and Bachtiar(2008) adopted the theory of Meredith (2002). This study states that entrepreneurial intention refers to the entrepreneurial characteristics of a person. These features include confidence, task-orientation and the outcomes, risk taking, leadership and originality.

Linking Social Support to Entrepreneurial Intention: Social support is a concept which is widely deliberated and discussed and has been described in the available literature as one of the determinants of an individual's behaviour(Sahban, Kumar, \& Ramalu, 2015). Greeve and Salaf (2003) suggested that a business takes more benefits from family members in the start-up phase. Other studies have described the strong positive impact of family members on entrepreneurial intention because they are the first source of sharing and discussing new business ideas and initial feedback (Aldrich, Reese \& Dubini, 1990; Rosenblatt, de Mik, Anderson \& Johnson, 1988). Fayolle et al. (2006) and Leon et al. (2007) found that students have better intention in dealing with entrepreneurship after having been exposed to entrepreneurship through their family.According to Rani (2012), family support has a strong influence on opportunity recognition, new venture creation, business decision-making and resource mobilization. As mentioned by Davidsson and Honig (as cited inBaughn, Cao, Le, Lim, \& Neupert, 2006), social support by family and friends, as well as by parents owning a business, have been shown to be related to the occurrence of entrepreneurs. The role of close friends and family may be even more substantial than the general normative support in driving an individual's perceived desirability to commence a new venture. Greve and Salaff (2003) emphasized the prominence of the family in the entrepreneurial social circle. Habsah and Faudziah (as cited in Rani, 2012) did a study among alumni students in Universiti Utara Malaysia. The respondents admitted that their spouse, parents and relatives encouraged them to take up a business. Habsah and Faudziah also revealed that the students who are not interested in entrepreneurship can be influenced by people around them in making an entrepreneurial decision. Therefore, their kin play a substantial role in their entrepreneurial decision.

Mustikawati and Bachtiar (2008) conducted a study that aimed to demonstrate empirically whether there exists any association between social support (parents) and the entrepreneurial intention of vocational students. The results of their study indicated a significantly positive influence of social support (parents) on entrepreneurial intention among vocational students. The result of this study shows that the greater the social support provided by parents to their children, the greater the interest of vocational students to be involved in entrepreneurship. Further, Suharti and Sirine(2011) asserted that there is a strong potential role of contextual factors, such as academic support and social support, in entrepreneurial intention among the students. In many cases, an entrepreneur's primary group members, such as family or extended family members provide him/her with the required capital along with other kinds of business support i.e., source of supply of materials, access to new markets and new product ideas and access to technology (Dyer \& Handler, 1994; Zafar et al., 2012). Another determinant of entrepreneurship attitude is prior exposure to business activity in the form of early exposure to the family business (Krueger, 1993). The study by Drennan, Kennedy and Renfrow (2005) identified that the perceptions about starting a new business are desirable for those who have expressed a positive posture of their family's business. Their study further described that early childhood experiences, such as adversity and frequent relocation, have significantly positive influence on an individual's attitude toward entrepreneurship. Other factors, such as prior exposure to business activities and prior attempt to start a new business have positive effects on the attitude towards entrepreneurship.

Researchers who have studied the influence of familial factors on entrepreneurial intention seem to have focused on the modelling influence and the family history of entrepreneurial activities. Carr and Sequeira (2007) revealed that experiences from family business tend to have a substantial intergenerational effect on entrepreneurial intentions. McElwee and Al-Riyami(2003) found that children having parents in businesses 
tend to display a higher propensity to engage in entrepreneurship. Mueller (2006) also concurred that when putting all personal factors influencing a person's entrepreneurial intention together, parental role modelling seems to be the most significant. Another factor believed to have a direct bearing on entrepreneurial intention in the family is the financial resources in the family. This is due to the fact that family members in business have the potential of becoming a mentor and source of financial and non-financial help (Ahmed et al., 2010). On the other hand, Anderson et al. (2005) found that the support from families is not directly related to entrepreneurial intention. Their study found that more than a quarter of vital entrepreneurial support perceived by young entrepreneurs is outside the support from their family and colleagues. The above literature offers incisive insights into the influence of the social support factor on entrepreneurial intention. It is shown that family and peer group factors considerably affect the entrepreneurial intention of the youth. Direct experience is coming out with the power of social support system thus may or may not have an influence on young students who are undergoing entrepreneurial exposure. Therefore, this study proposes the second hypothesis of the research, which is mentioned below:

H1: Social support is positively related to entrepreneurial intention among business students in Indonesia.

Gender and Entrepreneurship: There are increasing numbers of research conducted on female entrepreneurs; however, the comparison between gender in entrepreneurship has been less looked into (Yordanova \& Alexandrova-Boshnakova, 2011). Gender inequality exists in terms of economic development as well as the rates of entrepreneurial activity. There is a significant gender gap in the entrepreneurial activity rate worldwide (Allen as cited in Sarfaraz et al., 2014). The GEM Women's Report (as cited in Sarfaraz et al., 2014) states that the gender gap among entrepreneurs has gradually increased over time in some countries. Overall, as the economies move to a higher level of development, the rate of entrepreneurial activity decreases, regardless of gender. Sarfaraz et al. (2014) argued that gender equality may lead to an increasing number of female entrepreneurs. Consequently, one may conclude that in the economies where women are more likely to have equal opportunities with men, the equality of women entrepreneurial activity is higher compared to the economies where women face a greater rate of gender inequality. According to Malach-Pines et al. (2010) women's entrepreneurial intention in developed countries is likely to be lower compared to the ones in developing countries. Equal opportunities are of greater concern for women in developed countries than those in developing nations.

There is a consensus among researchers that women can play a substantial role in business activities (Sarfaraz et al., 2014). Olomi and Sinyamule(2009) conducted a research on the entrepreneurial intention of vocational students. They found that female students are more motivated to take up a business after the completion of their studies. They tend to choose different types of businesses offered by the company which is common for females. Another study by Zhao et al. (2005) also found that gender is directly associated with entrepreneurial intention. It is because women have reported having lower intentions to become entrepreneurs than men. In contrast, Keat et al. (2011)argued that male students have greater entrepreneurial intention compared to their female counterparts. Lucas \& Cooper (2012) stated that gender is generally regarded as having a consequential effect on entrepreneurial pursuits, as men are generally found to have a higher entrepreneurial self-efficacy than women and more likely to start companies. Apart from that, Franco, Haase and Lautenschlager (2010) did a study to examine the factors contributing to entrepreneurial intention among students in Europe. They revealed that the entrepreneurial intention among female students is the same as male students. Further, MoharYusof, Sandhu and Jain (2008) conducted a research on entrepreneurial intention among business students at Tun Abdul Razak University (UNITAR). They utilized T-test analysis to find the differences of perception among male and female students related to entrepreneurial career. It was revealed that both genders do not show difference in dealing with entrepreneurship. There are inconsistencies from previous researchers regarding gender in dealing with entrepreneurship. Some researchers argued that male students have higher entrepreneurial intention; meanwhile the opponents argued that female students were more entrepreneurially inclined compare to their male counterparts. Accordingly, this study attempts to pose the hypothesis as follow:

H2: There is a difference between male and female business students in dealing with entrepreneurship. 


\section{Methodology}

Business students from several universities in Indonesia are defined as the unit of analysis in this study; in other words, the unit of analysis is the individual. To be more specific, the unit of analysis of this study includes the students who are enrolled in the department of management, economics and accounting in the faculty of economics and business. In order to gather the data, this study utilized self-administered questionnaires and analyzed the data using SPSS version 22. This study conducted a cross-sectional survey targeting a sample of business students at the Indonesian higher education institutions both public and private. The items of both SSwere assessed on a ten-point Likert scale, while EI instruments were assessed on a five-point Likert scale. Using a convenience sampling method, 1,230 self-administered questionnaires were distributed to the business students at public and private universities across Indonesia. This data collection process yielded back with 381 usable responses that were used in the statistical analysis for assessing the relationship between SS and EI as well as the role of gender in dealing with entrepreneurship.

Table 1: Factor Analysis of Social Support

\begin{tabular}{|c|c|c|}
\hline \multirow{2}{*}{ CODE } & \multicolumn{2}{|c|}{ FACTORS } \\
\hline & FS & PS \\
\hline FS10 & .887 & \\
\hline FS5 & .832 & \\
\hline FS6 & .826 & \\
\hline FS14 & .819 & \\
\hline FS2 & .806 & \\
\hline FS3 & .794 & \\
\hline FS12 & .793 & \\
\hline FS8 & .763 & \\
\hline FS11 & .761 & \\
\hline FS7 & .708 & \\
\hline FS9 & .692 & \\
\hline FS4 & .685 & \\
\hline FS13 & .672 & \\
\hline FS15 & .647 & \\
\hline FS1 & .628 & \\
\hline PS6 & & .837 \\
\hline PS9 & & .835 \\
\hline PS3 & & .832 \\
\hline PS7 & & .806 \\
\hline PS4 & & .802 \\
\hline PS1 & & .793 \\
\hline PS8 & & .787 \\
\hline PS10 & & .776 \\
\hline PS2 & & .752 \\
\hline PS5 & & .736 \\
\hline Eigenvalue & 8.356 & 4.364 \\
\hline VE \% & 39.103 & 25.158 \\
\hline
\end{tabular}




\begin{tabular}{lll} 
Reliability & 0.802 & 0.843 \\
KMO & 0.937 & \\
Overall VE\% & 64.241 & \\
Chi-square & 547.068 & \\
Significance & 0.000 & \\
\hline FS : Family Support \\
PS : Peers Support
\end{tabular}

Social Support Instrument: In order to measure the variable of social support, the instrument of social support was adopted from Sahban, Kumar and Ramalu (2015). The items related to the dimensions of social support, i.e., friends support and family support was used in this study. The social support was measured with 25 items using a 10-point Likert scale (1=strongly disagree to 10=strongly agree). To test the validity and reliability, this instrument was subjected to pilot testing.80 questionnaires were conveniently handdistributed to students in Indonesia from both public and private universities, resulting in 65 valid responses. SS items were then coded as 1 and $2=$ strongly disagree, 3 and $4=$ disagree, 5 and $6=$ neutral, 7 and $8=$ agree, and 9 and $10=$ strongly agree and entered into SPSS for analysis. Having analysed through SPSS, the 25 items were retained since every item had factor loading more than 0.5 and consistently predicted the construct. In addition, these items explained $64.24 \%$ of variance cumulatively. Therefore, these items were not dropped. In addition, the Cronbach's alpha ranged from 0.802 to 0.843 , fulfilling eligibility to consider the factors of social support. Hence, this instrument could be considered for the data collection and analysis to explain the social support construct. The factor analysis of social support construct is presented in Table 1.

Entrepreneurial Intention Instrument: All the entrepreneurial intention items were adopted without alteration from Liñán and Chen $(2006,2009)$. The questionnaire has been used by Liñán(2008); Guerrero et al. (2009); Chen et al. (1998); and Zhao et al. (2005). The construct of entrepreneurial intention was measured using a five-point Likert scale ( $1=$ strongly disagree to $5=$ strongly agree). The use of five-point Likert scale was also found in previous entrepreneurial intent studies done by Gupta, Turban, Wasti and Sikdar(2009); Schwarz, Wdowiak, Almer-Jarz and Breitenecker(2009); and Malebana and Swanepoel(2011). The Cronbach's alpha for the entrepreneurial intent scale was 0.903 which met Nunnally and Bernstein's (1994)standard for scale development studies of 0.7.

To test the validity and reliability, this instrument was subjected to pilot testing. Since the original instruments were written in English, an expert translator translated the questionnaire from English into Indonesian. Then the translation was, blindly, back-translated from Indonesian to English by another translator. After that, the authors matched the translated copies to reach the most accurate translation and eliminate statements that gave different meanings (e.g. Brislin, 1980; Mahmoud \& D Reisel, 2014; Mahmoud, 2013). Hence, EI1, EI4 and EI9 were eliminated due to bad phrasing. The new copy was then reviewed by Professor from the Economics and Business Faculty, Indonesia University to guarantee face validity (Tharenou, Donohue, \& Cooper, 2007).Thereafter, the 80 questionnaires were also conveniently handdistributed to students in Indonesia from both public and private universities, resulting in 65 valid responses. EI items were then coded as $1=$ strongly disagree, $2=$ disagree, $3=$ neutral, $4=$ agree, and $5=$ strongly agree and entered into SPSS for analysis. As a result, the pilot test provided a reliable statistic, indicating the Cronbach's alpha of 0.925 , fulfilling the eligibility to consider the factors of entrepreneurial intention. The study further revealed that the eigenvalues exceeded 1, explaining cumulatively 0.640 of the variance. Hence, this instrument could be considered for the data collection and analysis to explain the students' intention to deal with entrepreneurship. Table 2 below described the factor analysis of entrepreneurial intention: 
Table 2: Factor Analysis of Entrepreneurial Intention

\begin{tabular}{ll}
\hline \multirow{2}{*}{ CODE } & FACTOR \\
\cline { 2 - 2 } & EI \\
\hline EI3 & 0.953 \\
EI5 & 0.952 \\
EI7 & 0.949 \\
EI8 & 0.792 \\
EI6 & 0.777 \\
EI2 & 0.762
\end{tabular}

Eigenvalue $\quad 4.828$

VE $\%$

Reliability $\quad 0.925$

KMO 0.901

Overall VE\% $\quad 64.052$

Chi-square $\quad 207.486$

Significance $\quad 0.000$

EI: Entrepreneurial Intention

\section{Results}

Validity and Reliability: Prior to examine the first hypothesis, this study attempted to test validity and reliability of the items through convergent validity and Cronbach alpha. Convergent validity is defined as the extent to which the items used to measure a construct share a high proportion of common variance (Hair, Black, Babin, \& Anderson, 2010). According to Churchill (1979), it is the extent to which different means of data collection produce the same results. In other words, convergent validity indicates the degree to which multiple items measure the same construct.The convergent validity is presented in Table 3 below:

Table 3: Convergent Validity

\begin{tabular}{llllll}
\hline & & & \multicolumn{2}{l}{ Convergent Validity } & \\
\cline { 5 - 6 } \cline { 5 - 5 } Construct & Items in Average & $\begin{array}{l}\text { Internal } \\
\text { Reliability } \\
\text { Cronbach's } \\
\text { Alpha }\end{array}$ & Loading & $\begin{array}{l}\text { Composite } \\
\text { Reliability }\end{array}$ & $\begin{array}{l}\text { Average } \\
\text { Variance } \\
\text { Extracted }\end{array}$ \\
\hline Social Support & FS-av & & 0.649 & & \\
\cline { 5 - 6 } & PS-av & 0.889 & 0.674 & 0.896 & 0.812 \\
$\begin{array}{lllll}\text { Entrepreneurial } \\
\text { Intention }\end{array}$ & EI-av & 0.891 & 0.798 & 0.948 & 0.755 \\
\hline
\end{tabular}

Based on Table 3 above, the results showed high factor loadings of the two variables, indicating that the convergent validity of the measures was established.

Hypothesis Testing: For further analysis, this study put the dimensions of social support in average. Consequently, there was only single dimension to be examined. The regression analysis is presented in table 4 below: 
Table 4: Examining Variables' predictive power

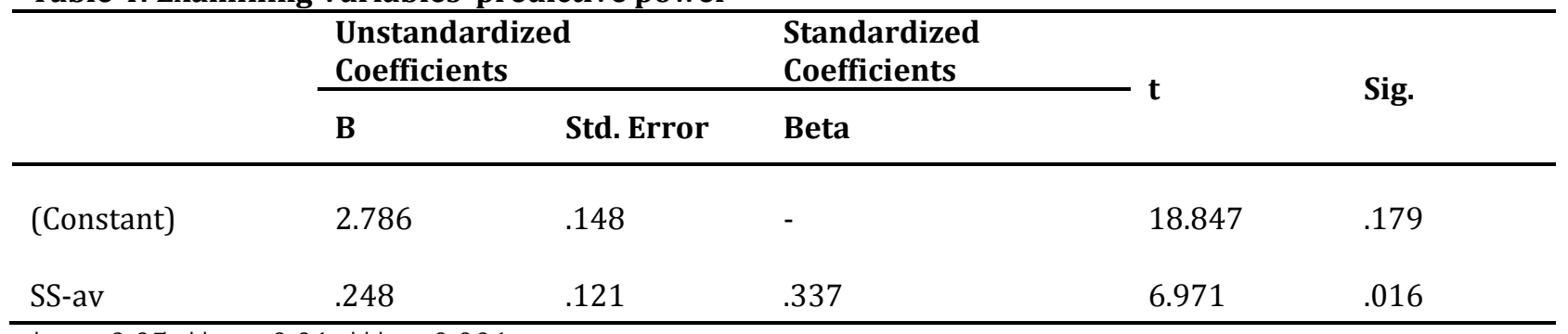

${ }^{*}: \mathrm{p}<0.05 ;{ }^{* *}: \mathrm{p}<0.01 ;{ }^{* * *}: \mathrm{p}<0.001$

Based on the table above, the t-value is 6.971 which is more than the threshold value of 1.96 (Nunally, 1978) and the significance value in this table shows 0.016 which is below than the threshold value of 0.05 , indicating that the null hypothesis was rejected. In other words, hypothesis 1 is supported whereby social support was positively influence student's intention to engage in entrepreneurial career. In order to test the difference between male and female students in term of entrepreneurial intention, independent sample T-test was employed and the result revealed that the entrepreneurial intention between both groups was different. Table 5 and 6 below describe the comparison of entrepreneurial intention between male and female students:

Table 5: Gender Distribution

\begin{tabular}{llllll}
\hline \multicolumn{6}{l}{ Group Statistics } \\
& Gender & N & Mean & Std. Deviation & $\begin{array}{l}\text { Std. Error } \\
\text { Mean }\end{array}$ \\
\hline \multirow{2}{*}{ Elav } & Male & 211 & 3.8544 & 0.64374 & 0.04432 \\
& Female & 170 & 3.7175 & 0.62214 & 0.04772 \\
\hline
\end{tabular}

Table 6: Independent Sample T-test

\begin{tabular}{|c|c|c|c|c|c|c|c|c|c|c|}
\hline & & $\begin{array}{l}\text { Leven } \\
\text { for } E \\
\text { of Vari }\end{array}$ & $\begin{array}{l}\text { s Test } \\
\text { uality } \\
\text { nces }\end{array}$ & t-test & or Equalit & of Mea & & & & \\
\hline & & \multirow[t]{2}{*}{$\mathbf{F}$} & \multirow[t]{2}{*}{ Sig. } & \multirow[t]{2}{*}{$\mathbf{T}$} & \multirow[t]{2}{*}{ df } & \multirow[t]{2}{*}{$\begin{array}{l}\text { Sig. } \\
(2- \\
\text { tailed } \\
\text { ) }\end{array}$} & \multirow[t]{2}{*}{$\begin{array}{l}\text { Mean } \\
\text { Differenc } \\
\text { e }\end{array}$} & \multirow[t]{2}{*}{$\begin{array}{l}\text { Std. Error } \\
\text { Difference }\end{array}$} & \multicolumn{2}{|c|}{$\begin{array}{l}95 \% \\
\text { Confidence } \\
\text { Interval of the } \\
\text { Difference }\end{array}$} \\
\hline & & & & & & & & & Lower & Upper \\
\hline $\begin{array}{l}\text { EI- } \\
\text { av }\end{array}$ & $\begin{array}{l}\text { Equal } \\
\text { variances } \\
\text { assumed }\end{array}$ & 1.448 & .230 & 2.093 & 379 & .037 & .13683 & .06536 & .00831 & .26535 \\
\hline & $\begin{array}{l}\text { Equal } \\
\text { variances not } \\
\text { assumed }\end{array}$ & & & 2.101 & 366.716 & .036 & 13683 & .06512 & .00877 & .26489 \\
\hline
\end{tabular}

As depicted in Table 5 above, the mean value of male students is slightly higher than female students. However, Table 6 depicts that there is a difference in both male and female students in terms of their intention to engage in entrepreneurial career. To interpret the output, the first row in Table 6 is used since the significance value in Levene's Test is more than 0.05 . It is clearly seen that the significance (2-tailed) is .037 , showing that there is a difference between the two groups in terms of engaging in entrepreneurship activities. Therefore, $\mathrm{H}$ null was rejected. 


\section{Discussion and Implication}

This study has achieved its research objectives in examining the relationship between SS and EI as well as the difference between male and female toward entrepreneurial intentionby utilizing SPSS version 22.Convergent validity and reliability test was also employed to ensure the combination of items to be able to measure the construct and to support the consistency of each item to measure the construct. It was hypothesized in this study that the social support is positively related to entrepreneurial intention. The result indicated that there is a positive relationship betweensocial supportand entrepreneurial intention among business students, meaning $\mathrm{H} 1$ is supported in this study. Past studies have supported this finding (Anderson et al., 2005; Baughn et al., 2006; Buang \& Yusof, 2006; León et al., 2007; Mustikawati \& Bachtiar, 2008; Procidano \& Heller, 1983; Rani, 2012) who have reported showing strong positive correlation between family support system and entrepreneurial intention. The findings of this study reveals that the higher the social support, the higher the entrepreneurial intention of the students to start-up a business. According to Rani, family support has a strong correlation with the occurrence of a new venture, opportunity recognition, decision-making as well as resource mobilization. In addition, a few related aspects, like environmental support and parental support, play an important role in influencing a person's desire for entrepreneurship (Indarti \& Rostiani, 2008; Lee, Wong, Foo, \& Leung, 2011; Suharti \& Sirine, 2011). Encouragement in the form of high motivation from the family to move forward is a core requirement to become a real entrepreneur. Thus, family support is of course the primary driving force to boost students' mentality and motivation (Kasmir, 2006). Parents with entrepreneurial professions are also role models for their children's career choice after graduating from the University.

The social support system has been shown to be paramount in developing entrepreneurial intention. The kinship relationships work as the strongest ties in entrepreneurial networks. Therefore, it is undeniable that parents play a significant role in providing support and motivation that will make their children become socially competent, confident and responsible in realizing their intention to become entrepreneurs. Based on these circumstances, people should develop a relationship and networking with other people to optimize their capacity, especially in conducting business. The network can also be a gateway that adds to competency ability and supplementary resources of an individual. In addition, the young graduates are supposed to get appropriate guidance and information from their peers and family members in order to get a better understanding about starting a business with appropriate resources. The students basically do not have too many ideas about how to run a business; they do not yet know how to look into aspects like finance management, pooling of resources, marketing the products, identifying right business opportunities, accessing better business networks and establishing business in right locations. These young students need to be given appropriate guidance from their family. According to this research, the higher the support the students get from their family, the higher the entrepreneurial intention will be. The result of the study thus indicates a strong correlation between students' SS and their intention to become entrepreneurs. Since this research employed non-probability sampling, further research need to be conducted by utilizing probability sampling as well as employing larger population in order to support the generalization of the outcomes.

\section{References}

Aaijaz, N. \& Ibrahim, M. D. (2013). Are Women Students More Inclined Towards Entrepreneurship? Journal of Business Review, 2(3).

Acs, Z. (2006). How is Entrepreneurship Good for Economic Growth? Retrieved December 20, 2014, from http://egateg.usaidallnet.gov/sites/default/files/How is Entrepreneurship Good for Growth.pdf

Ahmed, I., Nawaz, M. M., Ahmad, Z., Shaukat, M. Z., Usman, A., Rehman, W. U. \& Ahmed, N. (2010). Determinants of Students' Entrepreneurial Career Intentions: Evidence from Business Graduates. European Journal of Social Sciences, 15(2), 14.

Aldrich, H., Reese, P. R. \& Dubini, P. (1990). The go-between: Brokers' roles in entrepreneurial networks. In Paper presented at Babson College Entrepreneurship Conference.

Amalia. (2012). Kendala Berwirausaha Di Kalangan Mahasiswa. Retrieved from http://manajemen.unnes.ac.id/wp-content/uploads/2013/01/kendala-berwirausaha-dikalanganmahasiswa.pdf

Amrullah, A. (2012). Mayoritas Lulusan Perguruan Tinggi tak Tertarik Jadi Wirausahawan, Kok Bisa? 
Retrieved from http://www.republika.co.id/berita/nasional/umum/12/03/03/m0aira-mayoritaslulusan-perguruan-tinggi-tak-tertarik-jadi-wirausahawan-kok-bisa

Anderson, A. R., Jack, S. L. \& Dodd, S. D. (2005). The Role of Family Members In Entrepreneurial Networks: Beyond the Boundaries of the Family Firm. Family Business Review, 18(2), 135-154. doi:10.1111/j.1741-6248.2005.00037.x

Astuti, D. A. W. (2009). Pengaruh Konteks Keluarga, Kerja, Pendidikan, Hambatan Dalam Memulai Bisnis, Dukungan Sosial, Nilai - Nilai Individualisme dan Kolektivisme Pada Intensi Berwirausaha.

Balea, J. (2015). 12 women entrepreneurs who smashed the glass ceiling in Southeast Asia. Retrieved June 16, 2015, from https://sg.finance.yahoo.com/news/12-women-entrepreneurs-smashed-glass090054259.html

Baron, R. A. \& Shane, S. A. (2008). Entrepreneurship: A Process perspective (2nd ed.). Thomson South-Western.

Baughn, C. C., Cao, J. S. R., Le, L. T. M., Lim, V. A. \& Neupert, K. E. (2006). Normative, Social and Cognitive Predictors of Entrepreneurial Interest in China, Vietnam and the Philippines. Journal of Developmental Entrepreneurship, 11(1), 57-77.

Bönte, W., Falck, O. \& Heblich, S. (2009). The Impact of Regional Age Structure on Entrepreneurship. Economic Geography, 85(3), 269-287. doi:10.1111/j.1944-8287.2009.01032.x

Brislin, R. W. (1980). Translation and content analysis of oral and written materials. (J. . H.C. and Berry, Ed.). Triandis: Handbook of Cross-Cultural Psychology (Vol. 2) Allyn \& Bacon,Boston, MA.

Buang, N. A. \& Yusof, Y. M. (2006). Motivating Factors that Influence Class F Contractors to Become Entrepreneurs. Jurnal Pendidikan, 31, 107-121. Retrieved from http://journalarticle.ukm.my/186/1/1.pdf

Carr, J. C. \& Sequeira, J. M. (2007). Prior family business exposure as intergenerational influence and entrepreneurial intent: A Theory of Planned Behavior approach. Journal of Business Research, 60(10), 1090-1098. doi:10.1016/j.jbusres.2006.12.016

Chen, C. C., Greene, P. G. \& Crick, A. (1998). Does entrepreneurial self-efficacy distinguish entrepreneurs from managers? Journal of Business Venturing, 13(4), 295-316. doi:10.1016/S0883-9026(97)00029-3

Choo, S. \& Wong, M. (2006). Entrepreneurial Intention : Triggers and Barriers to New Venture Creations in Singapore. Singapore Management Review, 28(2), 47-65.

Drennan, J., Kennedy, J. \& Renfrow, P. (2005). Impact of childhood experiences on the development of entrepreneurial intentions. International Journal of Entrepreneurship \& Innovation, 6(4), 231-238.

Dyer, W. G. \& Handler, W. (1994). Entrepreneurship and Family Business: Exploring the Connections. Entrepreneurship Theory and Practice, 18, 71-83.

Falck, O., Heblich, S. \& Luedemann, E. (2009). Identity and entrepreneurship: do school peers shape entrepreneurial intentions? Small Business Economics, 39(2). doi:10.1007/s11187-010-9292-5

Fayolle, A., Gailly, B. \& Lassas-Clerc, N. (2006). Assessing the impact of entrepreneurship education programmes: a new methodology. Journal of European Industrial Training, 30(9), 701-720. doi:10.1108/03090590610715022

Franco, M., Haase, H. \& Lautenschläger, A. (2010). Students' entrepreneurial intentions: an inter-regional comparison. Education + Training, 52(4), 260-275. doi:10.1108/00400911011050945

Granovetter, M. S. (1973). The Strength of Weak Ties. American Journal of Sociology, 78(6), 1360-1380.

Greve, A. \& Salaff, J. W. (2003). Social Networks and Entrepreneurship. Entrepreneurship Theory and Practice, 28(1), 1-22. doi:10.1111/1540-8520.00029

Guerro, M., Lavin, J. \& Alvarez, M. (2009). The Role of Education on Start-up Intentions: A Structural Equation Model of Mexican University Students. In Association for Small Business \& Entrepreneurship 35th Annual conference. Victoria, Tamaulipas, Mexico.

Gupta, V. K., Turban, D. B., Wasti, S. A. \& Sikdar, A. (2009). The Role of Gender Stereotypes in Perceptions of Entrepreneurs and Intentions to Become an Entrepreneur. Entrepreneurship Theory and Practice, 33(2), 397-417. doi:10.1111/j.1540-6520.2009.00296.x

Gurbuz, G. \& Aykol, S. (2008). Entrepreneurial Intention of Young Educated Public in Turkey. Journal of Global Strategic Management, 4, 47-56.

Hair, J. F., Black, W. C., Babin, B. J. \& Anderson, R. E. (2010). Multivariate Data Analysis (7th ed.).

Hartanto, E. F. (2011). Kendala Berwirausaha di Indonesia. Retrieved December 11, 2013, from http://research.amikom.ac.id/index.php/KIM/article/view/3933/2272

Indarti, N. (2004). Factors Affecting Entrepreneurial Intentions Among Indonesian Students. Journal of Indonesian Economy and Business, 19(1), 57-70. Retrieved from 
http://jieb.feb.ugm.ac.id/catalog/index.php/jieb/article/view/626

Indarti, N. \& Rostiani, R. (2008). Intensi Kewirausahaan Mahasiswa : Studi Perbandingan Antara Indonesia, Jepang dan Norwegia Intensi Kewirausahaan Mahasiswa: Studi Perbandingan Antara Indonesia, Jepang dan Norwegia, 23(4), 1-27.

Indonesia-investments. (2014). Youth Unemployment in Indonesia: A Demographic Bonus or Disaster? Retrieved October 10, 2015, from http://www.indonesia-investments.com/id/news/newscolumns/youth-unemployment-in-indonesia-a-demographic-bonus-or-disaster/item2005

Indonesia-investments. (2015). Slowing Economy of Indonesia: Rising Youth Unemployment. Retrieved October 10, 2015, from http://www.indonesia-investments.com/news/news-columns/slowingeconomy-of-indonesia-rising-youth-unemployment/item5671

Ismail, A., Nor, S. M., Yahya, Z., Zahar, U. A. U., Ismail, Y. \& Samah, A. J. A. (2013). Social Support in Job Performance As An Antecedent of Work Intrusion on Family Conflict: Empirical Evidence. Management, 18(2), 37-55.

Kasmir. (2006). Kewirausahaan. Jakarta: Raja Grafindo Persada. Retrieved from http://library.um.ac.id

Katz, J. \& Gartner, W. B. (1988). Properties of Emerging Organizations, 13(3), 429-441.

Keat, O. Y., Selvarajah, C. \& Meyer, D. (2011). Inclination towards entrepreneurship among university students: An empirical study of Malaysian university students. International Journal of Business and Social Science, 2(4), 206-220.

Koe, W. L., Sa'ari, J. R., Majid, I. A. \& Ismail, K. (2012). Determinants of Entrepreneurial Intention Among Millennial Generation. Procedia - Social and Behavioral Sciences, 40, 197-208. doi:10.1016/j.sbspro.2012.03.181

Krueger, N. (1993). The Impact of Prior Entrepreneurial Exposure on Perceptions of New Venture Feasibility and Desirability. Entrepreneurship Theory and Practice, 18(1), 5-21.

Krueger, N., Reilly, M. D. \& Carsrud, A. L. (2000). Competing models of entrepreneurial intentions. Journal of Business Venturing, 15(5-6), 411-432. doi:10.1016/S0883-9026(98)00033-0

Kuswara, H. (2012). Strategi Perguruan Tinggi Mewujudkan Entrepreneurial Campus. Retrieved from http://www.dikti.go.id/?p=1328\&lang=id

Lee, L., Wong, P. K., Foo, M. Der, K. \& Leung, A. (2011). Entrepreneurial intentions: The influence of organizational and individual factors. Journal of Business Venturing, 26(1), 124-136. doi:10.1016/j.jbusvent.2009.04.003

Lee, S. H. \& Wong, P. K. (2004). An exploratory study of technopreneurial intentions: a career anchor perspective. Journal of Business Venturing, 19(1), 7-28. doi:10.1016/S0883-9026(02)00112-X

León, J. A. M., Descals, F. J. P. \& Domínguez, J. F. M. (2007). The Psychosocial Profile Of The University Entrepreneur. Psychology in Spain, 11(1), 72-84. Retrieved from http://www.psychologyinspain.com/content/full/2007/11007.pdf

Liñán, F. (2008). Skill and value perceptions: how do they affect entrepreneurial intentions? International Entrepreneurship and Management Journal, 4(3), 257-272. doi:10.1007/s11365-008-0093-0

Liñán, F. \& Chen, Y. (2006). Testing The Entrepreneurial Intention Model on a Two- Country Sample. Retrieved November 11, 2014, from http://www.recercat.net/bitstream/handle/2072/2213/ UABDT06-7.pdf Accessed: 28 August 2007.;jsessionid=BFCCCF40E951DE58F24F2BE90ED209D8.recercat1?sequence $=1$

Liñán, F. \& Chen, Y. (2009). Development and Cross-Cultural Application of a Specific Instrument to Measure Entrepreneurial Intentions. Entrepreneurship Theory and Practice, 33(3), 593-617. doi:10.1111/j.1540-6520.2009.00318.x

Lucas, W. A. \& Cooper, S. Y. (2012). Theories of Entrepreneurial Intention and the Role of Necessity. Retrieved November 23, 2014, from www.isbe.org.uk/content/assets/3.WilliamLucas.pdf

Mahmoud, A. B. (2013). Syrian Consumers: Beliefs, Attitudes, and Behavioral Responses to Internet Advertising. Business: Theory and Practice, 14(4), 297-307. doi:10.3846/btp.2013.31

Mahmoud, A. B. \& D Reisel, W. (2014). Relating patient satisfaction to nurses' job satisfaction, job security, and obedience OCBs. International Journal of Pharmaceutical and Healthcare Marketing, 8(1), 47-61. doi:10.1108/IJPHM-01-2013-0001

Malach-Pines, A., Lerner, M. \& Schwartz, D. (2010). Gender differences in entrepreneurship. Equality, Diversity and Inclusion: An International Journal, 29(2), 186-198. doi:10.1108/02610151011024493

Malebana, M. J. \& Swanepoel, E. (2011). The Relationship Between Exposure to Entrepreneurship Education And Entrepreneurial Self-Efficacy. Retrieved November 11, 2014, from 
http://www.unisa.ac.za/contents/faculties/service_dept/docs/Sabview_18_1_Chap 1.pdf

Masykur, A. M. (2007). Kewirausahaan Pada Mahasiswa Ditinjau Dari Adversity Quotient. Jurnal Psikologi Proyeksi, 2(2), 37-45.

McElwee, G. \& Al-Riyami, R. (2003). Women entrepreneurs in Oman: some barriers to success. Career Development International, 8(7), 339-346. doi:10.1108/13620430310505296

Mead, S., Hilton, D. \& Curtis, L. (2001). Peer support: a theoretical perspective. Psychiatric rehabilitation journal, 25(3).

Meredith, G. (2002). Kewirausahaan (Teori dan Praktek) Seri Manajemen Strategis. Jakarta: LPPM.

Morrison, A., Breen, J. \& Ali, S. (2003). Small Business Growth: Intention, Ability, and Opportunity. Journal of Small Business Management, 41(4), 417-425. doi:10.1111/1540-627X.00092

Mueller, P. (2006). Entrepreneurship in the Region: Breeding Ground for Nascent Entrepreneurs? Small Business Economics, 27(1), 41-58. doi:10.1007/s11187-006-6951-7

Musa, B. M. \& Semasinghe, D. M. (2013). Entrepreneurship And Unemployment: A Literature Review. In International Conference on Business \& Information 2013 (p. 2). Nigeria.

Mustikawati, I. \& Bachtiar, M. (2008). Hubungan Antar Dukungan Sosial (Orang Tua) Dengan Minat Berwirausaha Pada Siswa Sekolah Menengah Kejuruan. Fakultas Psikologi dan Ilmu Sosial Budaya, Universitas Islam Indonesia. Yogyakarta.

Nastiti, T., Indarti, N. \& Rostiani, R. (2010). Minat Berwirausaha Mahasiswa Indonesia dan Cina. Manajemen \& Bisnis, 9(2), 188-189.

Nunally, J. (1978). Psychometric Theory. McGraw-Hill: New York, NY.

Nunnally, J. C. \& Bernstein, I. H. (1994). Psychometric Theory (3rd ed.). New York, NY: McGraw-Hill.

Olomi, D. R. \& Sinyamule, R. S. (2009). Entrepreneurial Inclinations of Vocational Education Students: Comparative Study of Male and Female Trainees in Iringa Region, Tanzania. Journal of Enterprising Culture, 17(01), 103-125. doi:10.1142/S0218495809000242

Procidano, M. E. \& Heller, K. (1983). Measures of perceived social support from friends and from family: Three validation studies. American Journal of Community Psychology, 11(1), 1-24. doi:10.1007/BF00898416

Rani, S. H. B. A. (2012). A Study of Relationship Between Family Support, Role Model and Financial Support Towards Entrepreneurial Inclination Among UUM Non-Business Student. Universiti Utara Malaysia.

Revenga, A. \& Shetty, S. (2012). Empowering Women Is Smart Economics. Finance and Development, 49(1). Retrieved from http://www.imf.org/external/pubs/ft/fandd/2012/03/revenga.htm

Rosenblatt, P. C., de Mik, L., Anderson, R. \& Johnson, P. (1988). The Family in business. San Francisco: JosseyBass.

Sahban, M. A., Kumar M, D. \& Sri Ramalu, S. (2014). Model Confirmation through Qualitative Research: Social Support System toward Entrepreneurial Desire. Asian Social Science, 10(22), 17-28. doi:10.5539/ass.v10n22p17

Sahban, M. A., Kumar, D. \& Ramalu, S. S. (2015). Instrument Development: Entrepreneurial Social Support Assessment Instrument (IESSA). Research Journal of Economic \& Business Studies, 4(3), 21-36.

Sarason, I. G., Sarason, B. R., Shearin, E. N. \& Pierce, G. R. (1987). A Brief Measure of Social Support: Practical and Theoretical Implications. Journal of Social and Personal Relationships, 4(4), 497-510. doi:10.1177/0265407587044007

Sarfaraz, L., Faghih, N. \& Majd, A. A. (2014). The Relationship Between Women Entrepreneurship and Gender Equality. Journal of Global Entrepreneurship Research, 2(6), 2-11. Retrieved from http://www.journal-jger.com/content/pdf/2251-7316-2-6.pdf

Schumpeter, J. A. (1934). The Theory of Economic Development: An Inquiry Into Profits, Capital, Credit, Interest, and the Business Cycle. Cambridge MA: Harvard University Press.

Schwarz, E. J., Wdowiak, M. A., Almer-Jarz, D. A. \& Breitenecker, R. J. (2009). The effects of attitudes and perceived environment conditions on students' entrepreneurial intent. Education + Training, 51(4), 272-291. doi:10.1108/00400910910964566

Segal, G., Borgia, D. \& Schoenfeld, J. (2005). The motivation to become an entrepreneur. International Journal of Entrepreneurial Behaviour \& Research, 11(1), 42-57. doi:10.1108/13552550510580834

Shane, S., Locke, E. A. \& Collins, C. J. (2003). Entrepreneurial motivation. Human Resource Management Review, 13(2), 257-279. doi:10.1016/S1053-4822(03)00017-2

Stewart, A. (2003). Help One Another, Use One Another: Toward an Anthropology of Family Business. Entrepreneurship Theory and Practice, 27(4), 383-396. doi:10.1111/1540-8520.00016 
Subachtiar, F. T. (2013). Karakteristik dan Perilaku Wirausaha Mahasiswa Pengusaha di Institut Pertanian Bogor. Institut Pertanian Bogor.

Suharti, L. \& Sirine, H. (2011). Faktor-Faktor yang Berpengaruh Terhadap Niat Kewirausahaan ( Entrepreneurial Intention ) ( Studi Terhadap Mahasiswa Universitas Kristen Satya Wacana, Salatiga ). Junal Manajemen Dan Kewirausahaan, 13(2), 124-134.

Supatra, A. A. (2009). Intensi Berwirausaha Pada Mahasiswa Ditinjau Dari Self Efficacy. Universitas Katolik Soegijapranata, Semarang.

Susanti, N. (2012). Hubungan Antara dukungan Sosial Dan Daya Juang Dengan Orientasi Wirausaha Pada Mahasiswa Program Profesi Apoteker Universitas Ahmad Dahlan, Yogyakarta. Retrieved from uadjournal.com/index.php/EMPATHY/article/download/1548/886?

Sutarto. (2012). Minat Wirausaha Mahasiswa Masih Rendah. Retrieved December 12, 2013, from http://www.lensaindonesia.com/2012/02/21/minat-wirausaha-mahasiswa-masih-rendah.html

Temonsoejadi.com. (2013). Mengapa Mahasiswa Harus Berwirausaha? Retrieved December 11, 2013, from http://palupimanajemen.lecture.ub.ac.id/2013/02/mengapa-mahasiswa-harus-berwirausaha/

Tharenou, P., Donohue, R. \& Cooper, B. (2007). Management Research Methods. Cambridge University Press, New York, NY.

Yordanova, D. I. \& Alexandrova-Boshnakova, M. I. (2011). Gender effects on risk-taking of entrepreneurs: evidence from Bulgaria. International Journal of Entrepreneurial Behaviour \& Research, 17(3), 272295. doi:10.1108/13552551111130718

Yusof, M., Sandhu, M. S. \& Jain, K. K. (2008). Entrepreneurial Inclination of University Students: A Case Study of Students At Tun Abdul Razak University (UNITAR), 4(1).

Yusuf, A. T. (2012). Evaluasi Program Mahasiswa Wirausaha Di Universitas Hasanuddin. Retrieved from http://222.124.222.229/bitstream/handle/123456789/2086/AndiTaufiqYusufE21108264.pdf?seq uence $=1$.

Zafar, M., Yasin, G. \& Ijaz, M. (2012). Social Networking A Source For Developing Entrepreneurial Intentions Among Entrepreneurs: A Case of Multan. Asian Economic and Financial Review, 2(8), 1072-1084. Retrieved from journal homepage: http://aessweb.com/journal-detail.php?id=5002.

Zhao, H., Seibert, S. E. \& Hills, G. E. (2005). The mediating role of self-efficacy in the development of entrepreneurial intentions. The Journal of Applied Psychology, 90(6), 1265-72. doi:10.1037/00219010.90.6.1265. 